\title{
DEVELOPMENT OF PHOTONOVELA WITH CHARACTER EDUCATION: AS AN ALTERNATIVE OF PHYSICS LEARNING MEDIA
}

\author{
Farida Ariyani*1, Taras Nayana ${ }^{2}$, Antomi Saregar ${ }^{3}$, Yuberti $^{4}$, Agitha Pricilia ${ }^{5}$ \\ ${ }^{1,5}$ Faculty of Education and Teacher Training, University of Lampung, Lampung, Indonesia \\ 2, 3,4 Physics Education Department, Universitas Islam Negeri Raden Intan, Lampung, Indonesia \\ *Correspondence address: dulifarida@ gmail.com
}

Received: June $14^{\text {th }}, 2018$. Accepted: October 07 ${ }^{\text {th }}, 2018$. Published: October $28^{\text {th }}, 2018$

\begin{abstract}
The internalization of character education in science learning through a variety of learning media has been researched recently, one of which is through the photonovela media which is the medium of insertion of character values in learning material. The focus of this research is; 1) developing photonovela learning media with character education on work material and energy, 2) knowing photonovela media feasibility as a supplement to physics learning with character education on work material and energy 3) knowing the response of students to photonovela media with character education in an energy material. This research is a Research and Development study adopted the development of Borg and Gall with the subject of junior high school students. The research instruments used were questionnaires by material experts, media experts, and junior high school physics teachers and questionnaires for students' responses in the three schools. The results of the assessment by material experts obtained a percentage of $85 \%$, the assessment of media experts was $90 \%$, and the assessment of junior high school teachers was $84.16 \%$, while the response of students in three junior high schools was 87.6\%, 94\%, and 93.6\%. In conclusion, this study produced a product in the form of appropriate photonovela media as a supplement to physics learning with character education on business material and energy.
\end{abstract}

(C) 2018 Physics Education, UIN Raden Intan, Lampung, Indonesia.

Keywords: character education, energy, media photonovela, work

\section{INTRODUCTION}

The values of character education can be developed, integrated and internalized with students through the learning process, including in physics learning (Anwar, 2017; Diani, 2015; Khoiron \& Sutadji, 2012; Maiyena, 2013; Nurhuda, Waluyo, \& Suyitno, 2017). Physics is known as science that is very closely related to human behavior and life (Saregar, 2016; Venisari, Gunawan, \& Sutrio, 2015). This shows that the competencies students must possess are not only limited to cognitive abilities but also the character of students (Sole \& Anggraeni, 2016; Widyaningsih \& Yusuf, 2015). While all this time learning physics still focuses on cognitive aspects only (Mujizatullah, 2018).
The problem of most students is that physics is difficult to understand (Chhetri, 2017; Hofer, Schumacher, Rubin, \& Stern, 2018; Irmawati, Djalaluddin, \& Wahyuni, 2017; Irwandani, Latifah, Asyhari, Muzannur, \& Widayanti, 2017; Rosdianto, Murdani, \& Hendra, 2017; Sugiana, Harjono, \& Sahidu, 2016), one of the causes is the lack of proper use of learning media used by teachers (Agustin, Bektiarso, \& Bachtiar, 2018), so students can hardly observe the mechanism that occurs during learning activities (Weng, Lin, \& She, 2017), preferably the previous learning conditions should be improved (Saregar, Latifah, \& Sari, 2016), so students play an active role in the learning process (Haruehansawasin \& Kiattikomol, 2018). 
Education is currently facing the challenges of the fourth industrial revolution or Industry 4.0 (Ciffolilli \& Muscio, 2018). The teacher as a facilitator must be skilled in mastering various models and learning media that are in accordance with the characteristics of the material to be delivered (Barus \& Sani, 2017; Suranti, Gunawan, \& Sahidu, 2016; Suryani, Sakti, \& Purwanto, 2018), using or making interesting learning media, so learning materials are easy to understand (Ardiyanti, Usman, \& Bandu, 2018; Saregar, Diani, \& Kholid, 2017; N. Sari, Suryanti, Manurung, \& Sintia, 2017; Suyanto, 2018), and encourage students actively in the learning process (Abdurrahman, Saregar, \& Umam, 2018).

The types of learning media that are relevant include; information technologybased learning media (I. A. D. Astuti, Nurullaeli, \& Nugraha, 2018), and rack and pinion type media (Rubiyanto \& Susanto, 2018), as well as other learning media that can be used to facilitate the learning process, in this case selected learning media to shape the character of students as learners, the selected media is photonovela learning media.

Photonovela is a media that resembles comics or picture stories, using photographs as a substitute for illustrated images (Anggia \& Dra. An Fauzia Rozani Sy., 2014; Herdiani, Maskur, \& Noordyana, 2017). The general characteristics of this media are some of them that; easy to make yourself in a simple manner, in accordance with the students 'emotions and the theme in this media is based on the students' real conditions with the intention that students are easier to understand (Widyaningrum \& Prihastari, 2018), then aim to determine the direction of learning activities, in order to be able to practice character values to students (Oktaviani, Yulkifli, \& Murtiani, 2017; R. T. Sari \& Jusar, 2017), one of the advantages of this media is that space and time limitations can be overcome (Yusro
\& Sasono, 2016). So that the students will feel helping in the learning (E.P, Bektiarso, \& Gani, 2017). So, the learning media occupies an important position as one of the supporting components in the learning system (Muslina, Abdul, \& Ibnu, 2017; Ramadhanti, Edwita, \& Sumantri, 2018; Setiawan, Arifin, \& Ardianto, 2018; Widada \& Rosyidi, 2017).

Photonovela media is not only used in the field of education but in the field of health media is often used as an alternative media, this is in accordance with previous research that produced local wisdombased photonovela learning media on the subject of effective and practical Newton law (Rahayu, Sutikno, \& Masturi, 2015), in the field of health explains photonovela is able to increase knowledge of depression and reduce stigma among Hispanic adults (Unger, Cabassa, Molina, Contreras, \& Baron, 2013), then photonovela is able to increase knowledge, attitudes, and intentions of human papillomavirus vaccine in the community Hispanic income is low (Chan, Brown, Sepulveda, \& Teran-Clayton, 2015). Furthermore, it can influence Dutch adults with varying levels of literacy to find out about diabetes by reading photonovela (Koops van 't Jagt et al., 2018).

Different from this research and development from previous research, researchers will develop photonovela media with character education, in the form of inserting character values on each material, then choosing different materials namely business and energy, as well as the conditions of different schools and places.

\section{METHOD}

\section{Research Design}

This research is a research and development that uses Borg \& Gall procedural models. Procedural models are descriptive models that describe procedural steps that must be followed to produce products (Wicaksono, Roekhan, \& Hasanah, 2018). 
In the stages of development research consist of 10 development steps (Nugraha, 2017). The tenth steps are not all to be done, the researcher just adopt seven steps because they have answered the research objectives that test the attractiveness and feasibility of learning media as a supplement to physics learning with character education. The seven-step procedure carried out by researchers is:

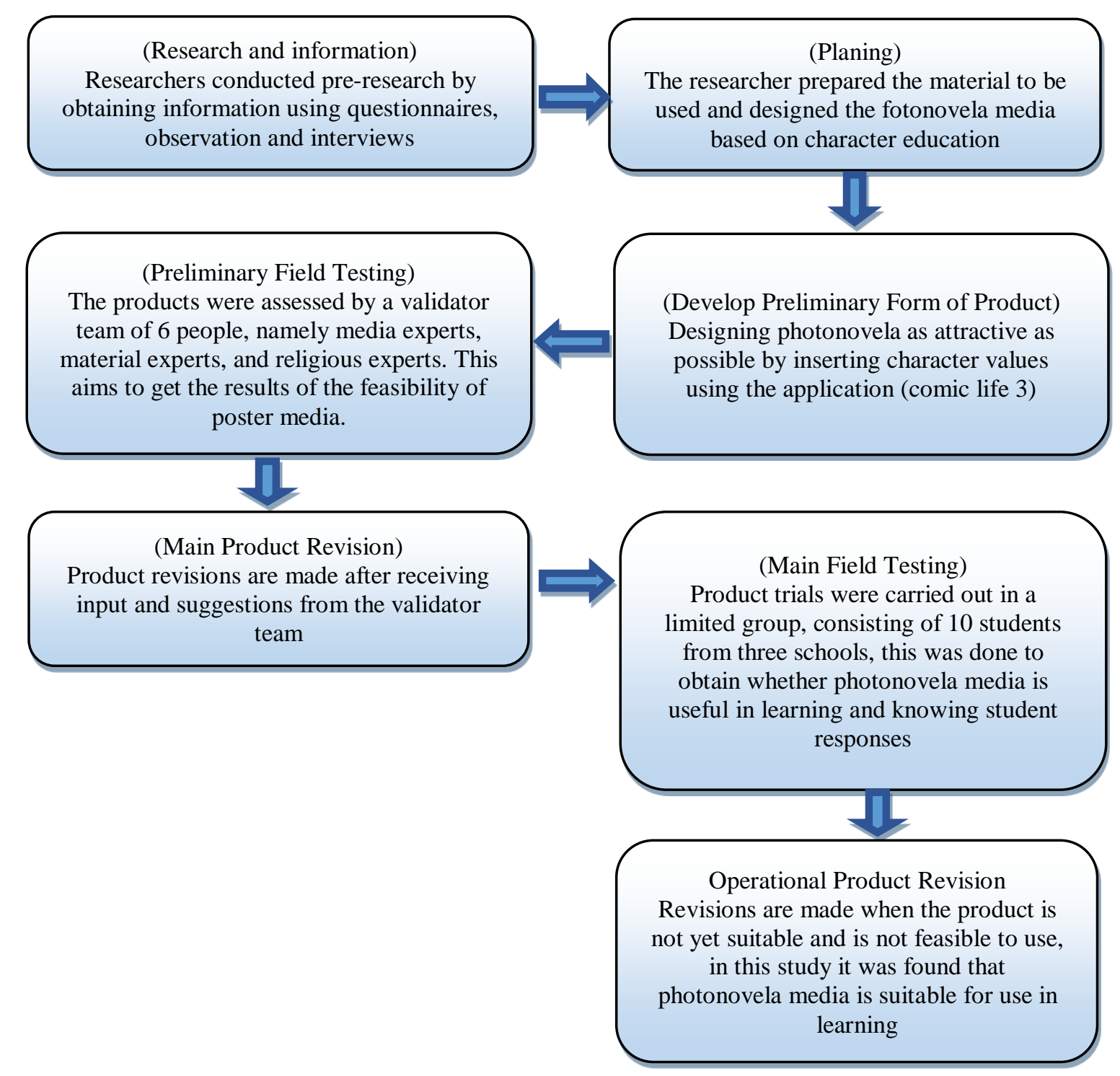

Figure 1. The research procedures of Borg and Gall 
The results of the product are feasible or not, and student responses are measured using research instruments in the form of questionnaires by material experts, media experts, junior high school physics teachers and questionnaires for students' responses in the three schools.

\section{Data Analysis}

The data of research was collected using expert validation sheets, educator response sheets. The student response sheets and then the validation data were analyzed using a Likert scale (Adawiyah, Lesmono, \& Prastowo, 2018).

Calculate the percentage of eligibility of each aspect with the Likert scale formula (Asyhari \& Silvia, 2016):

Information:

$$
\mathrm{N}=\frac{\sum x}{\sum_{x i}} x 100 \%
$$

$$
\begin{aligned}
\mathrm{P} & =\text { Percentage } \\
\sum x & =\text { Number of respondents' answers in } \\
& 1 \text { item } \\
\sum_{x i} & =\text { Number of the ideal score in item }
\end{aligned}
$$

\section{Rating Score}

Changes in the results of the assessment of media experts, material experts, educators and responses of students from letters to scores are the provisions in the following figure 2 .

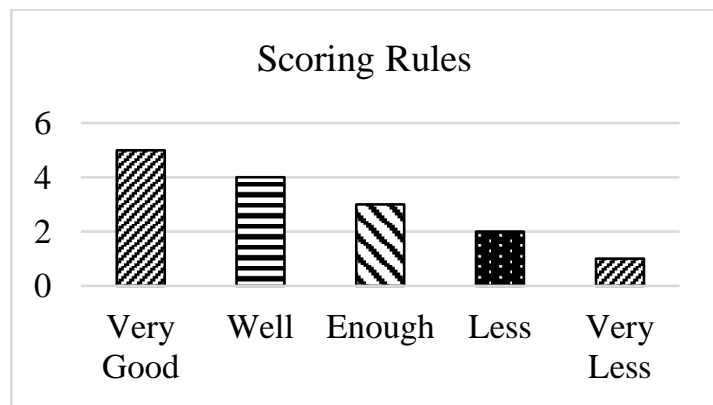

Figure 2. Scoring rules

To determine the feasibility of photonovela media as a supplement to physics learning, it contains character education in business and energy material, namely by giving respondents respite.
The result of percentage score obtained from the study is interpreted on the scale of interpretation of criteria in the following Table 1.

Table 1. Scale of Intrepretation Criteria (Damayanti, Komikesari, Syafei, \& Rahayu, 2018).

\begin{tabular}{cc}
\hline Percentage & Criteria \\
\hline $80 \%<\mathrm{P} \leq 100 \%$ & Very decent \\
$60 \%<\mathrm{P} \leq 80 \%$ & Decently \\
$40 \%<\mathrm{P} \leq 60 \%$ & Enough decent \\
$20 \%<\mathrm{P} \leq 40 \%$ & Less decent \\
$0 \% \leq \mathrm{P} \leq 20 \%$ & Very less decent \\
\hline
\end{tabular}

In Table 1 the scale of interpretation criteria the researchers can see the percentage of the results of the feasibility assessment or not the product to serve as a learning medium.

\section{RESULTS AND DISCUSSION \\ Result of Research}

The researcher presents the results of the products developed, namely the photonovela media as a supplement to physics learning with character education. The cover of photonovela media developed can be seen in the following figure 3 .

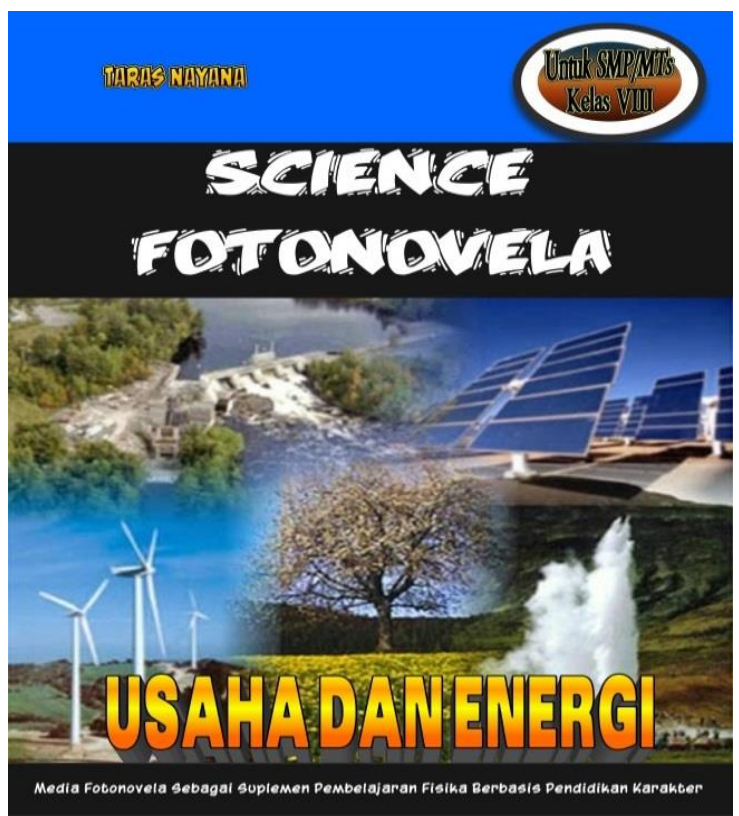

Figure 3. Cover media photonovela 
Figure 3 is a photonovela cover developed. Photonovela media with the insertion of character values on energy material, using photographs obtained from the results of the shoot.

After the product was successfully developed and tested its feasibility byproduct validation. The following are the results of the feasibility test;

\section{Validation of Material Expert}

The results of the validation of the material expert assessment on the product can be seen in the following figure 4 .

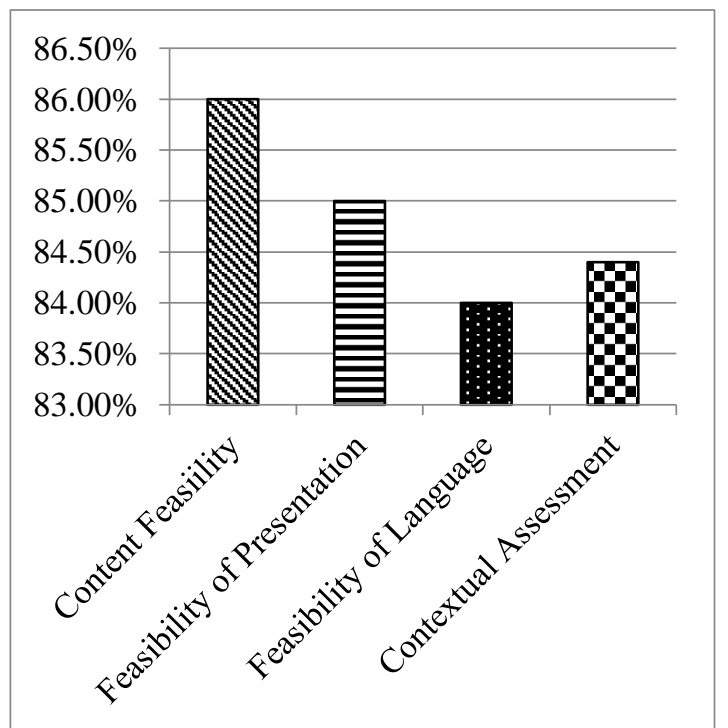

Figure 4. Percentage of material assessment

Based on Figure 4, the percentage of material expert validator evaluations on the aspect of content eligibility with business and energy material obtained a percentage of $86 \%, 85 \%$ percentage of the feasibility of presentation evaluation, $84.40 \%$ for language feasibility assessment, and 84 for the contextual assessment. $40 \%$, all proceeds of the percentage are stated as very feasible.

\section{Validation of Media Expert}

The results of the validation of media expert judgment on the product can be seen in the following figure 5 .

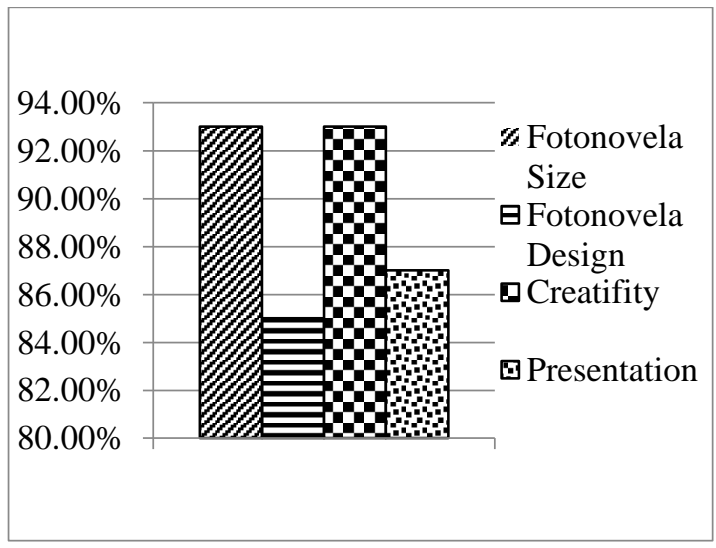

Figure 5. Results of evaluation by media experts

Based on Figure 5, the percentage of media expert validator evaluations on the photonovela size aspect obtained a percentage of $93 \%$, the photonovela design assessment obtained a percentage of $85 \%$, the creativity assessment got a percentage of $93 \%$, and the percentage assessment was $87 \%$, the very decent category expressed all percentage results.

\section{Validation of SMP/MTs Educators in Three Schools}

The results of validation by SMP AlHuda Jati Agung, MTs Muhammadiyah Sukarame Bandar Lampung, and SMP N 1 Gisting, can be seen in the following figure 6.

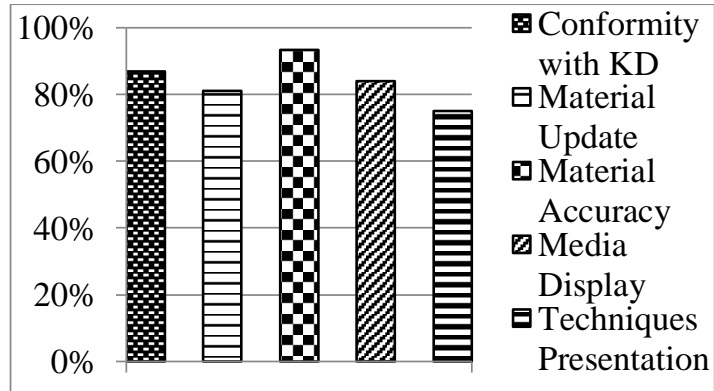

Figure 6. Results of validation by educators in Schools

Based on Figure 6, the percentage of the results of the three School educators' assessment of the material suitability aspects with basic competencies (KD) obtained a percentage of $87 \%$,

the material assessment obtained a percentage of $81 \%$, the assessment of the accuracy of the material obtained a 
percentage of $93.30 \%$, evaluation of media appearance obtained percentage by $84 \%$, the percentage results are expressed as very feasible, then the evaluation of the presentation technique is $75 \%$ with a decent category.

\section{The response of Students in Three Schools}

The results of trials on students can be seen in Figure 7 below.

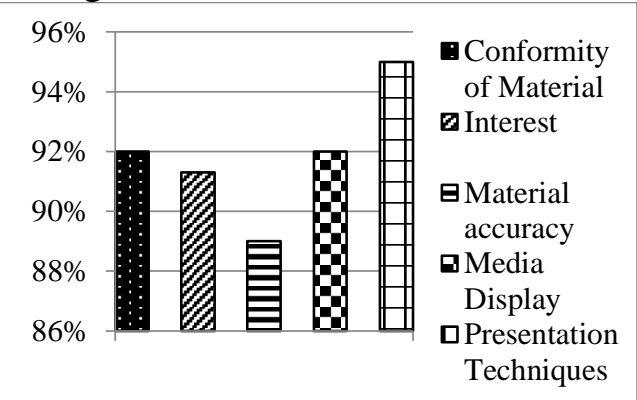

Figure 7. Results of the Response of Students in Schools

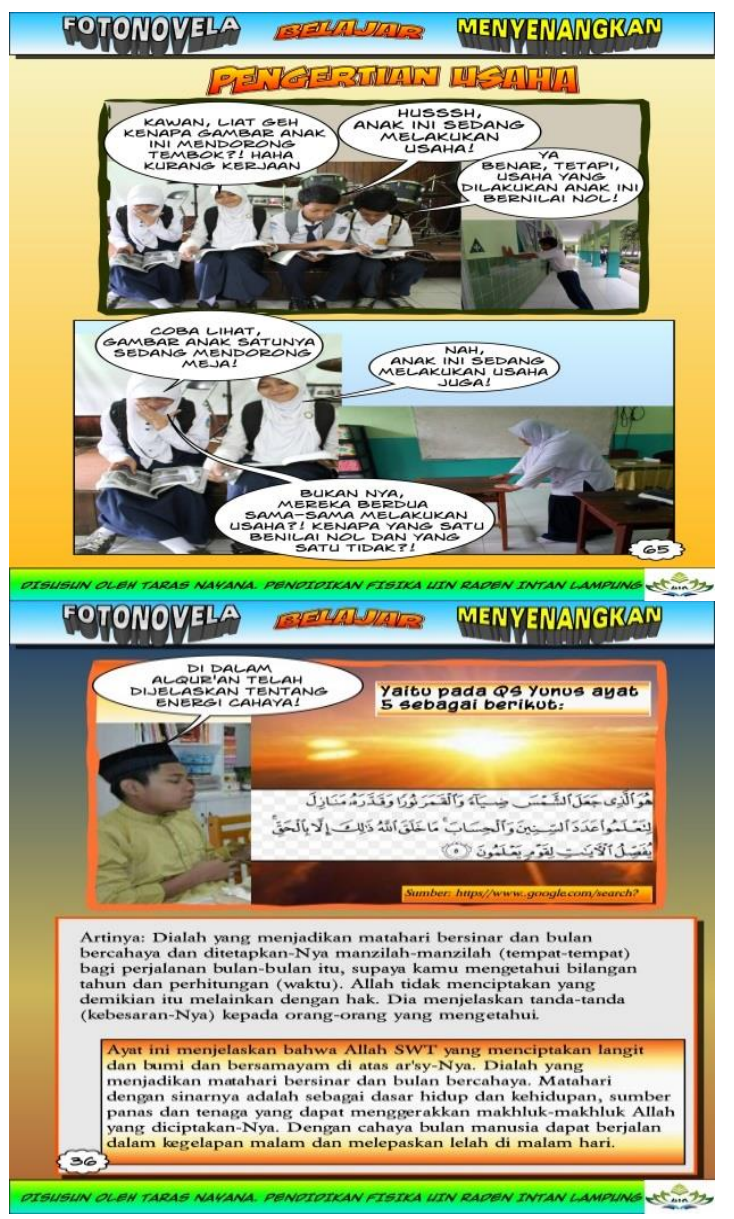

Based on Figure 7, the percentage of the results of field trials on students in the three schools in the material suitability aspects with basic competencies obtained a percentage of $92 \%$, an interest assessment obtained a percentage of $91.30 \%$, an assessment of the accuracy of the material obtained by $89 \%$, an assessment of media appearance obtained percentage at $92 \%$, then the assessment on the presentation technique obtained a percentage of $95 \%$ of the results of all percentages included in the very feasible category.

\section{DISCUSSION}

The results of a product that have been developed, namely photonovela learning media received a positive assessment by students as product users. Some product results can be seen in Figure 8 below,

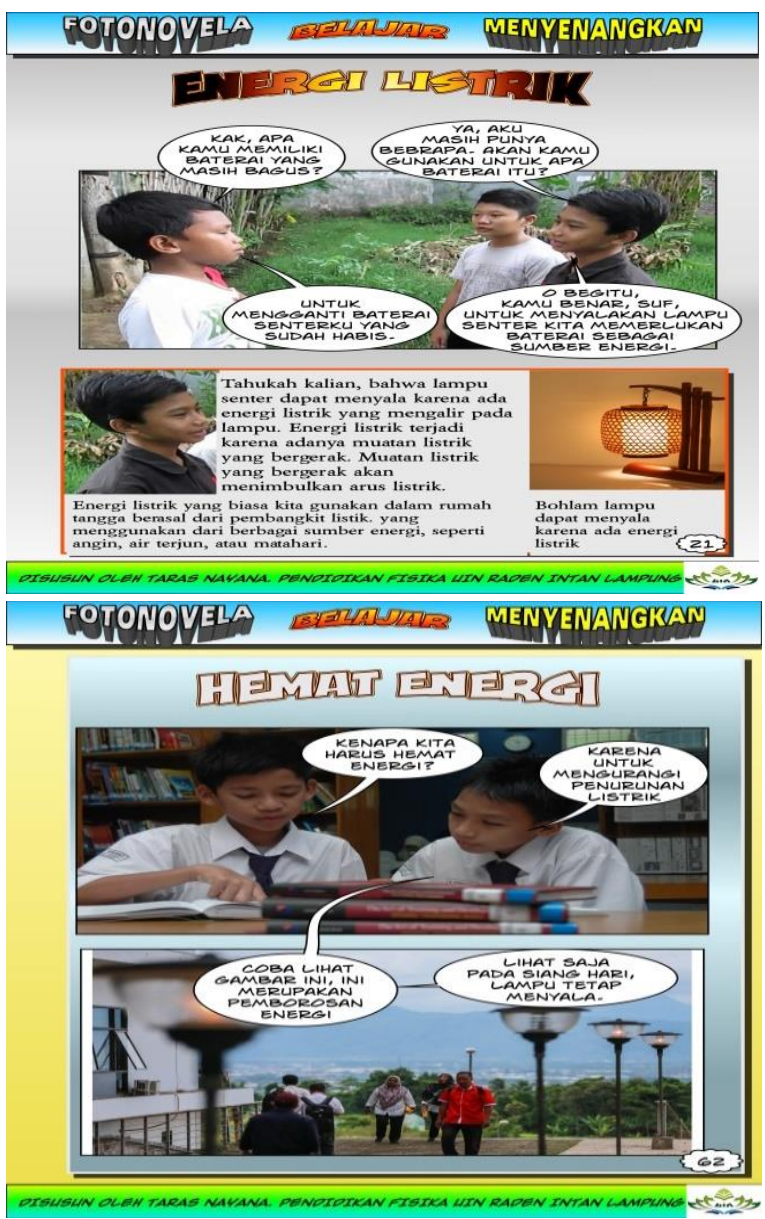

Figure 8. Footage of content on the results of photonovela media development 
Figure 8 , it shows that the product developed contains character values in business and energy material, using photographs obtained from the results of shooting and equipped with the material, examples of questions and evaluations that can be used in student learning to be more interesting. In accordance with its characteristics, the theme of the media is based on the real conditions of students with the aim that students more easily understand the material presented.

The products developed have been validated by six experts including three material experts and three media experts with the results of material validation, media expert validation, validation by junior high school / Madrasah educators in the three schools, and responses from students in all three schools. Then in each aspect of the assessment to obtain a percentage ranging from $75 \%$ to $95 \%$, the products included in the category of decent to very feasible. Photonovela learning media helps students to be able to study physics material either independently, in groups or learning with teachers in class. Through this media students are not only required to obtain good cognitive values, but the insertion of character values in the media is able to influence student character education, where students not only understand the material presented but students naturally learn character values that able to educate students' behavior so that positive habits are embedded in each learning activity. In line with previous research was that succeeded in increasing students' motivation and creative thinking abilities using photonovela media (P. Astuti, 2017).

The advantages of photonovela learning media found after research include: 1) Photonovela can motivate students during the teaching and learning process; 2) Photonovela consists of images which are media that can improve the quality of learning; 3) Photonovela is permanent and able to integrate character values through learning; 4) Photonovela can generate interest in reading and direct students to read discipline especially those who do not like to read; 5) Photonovela is part of popular culture.

The disadvantages of photonovela learning media found after research include: 1) Photonovela limits even allowing the killing of imagination; 2) Submission of subject matter through photonovela media is too simple and may be developed again; 3) The use of photonovela media is only effective in visual-style students.

\section{CONCLUSION AND SUGGESTION Conclusion}

This research concluded that photonovela learning media with character education can provide a more interesting learning atmosphere by inserting character education each learning using photonovela media. Then photonovela learning media as a supplement to physics learning with character education is worthy of being used in learning. The results of the trials carried out were small group trials from three schools that obtained an average percentage of eligibility of $88.3 \%$ with a very feasible category. In the field trials conducted in three schools, the average percentage of feasibility was $92 \%$ with a very feasible category to be implemented in learning in class and outside the classroom.

\section{Suggestion}

The use of photonovela learning media can affect student character education. From the results of this research can be carried out further research on learning with photonovela learning media for different concepts or topics. In making photonovela learning media with character education on work material and energy there are several obstacles or difficulties that might be an improvement for future researchers. 


\section{REFERENCES}

Abdurrahman, A., Saregar, A., \& Umam, R. (2018). The Effect of Feedback as Soft Scaffolding on Ongoing Assessment Toward The Quantum Physics Concept Mastery of The Prospective Physics Teachers. Jurnal Pendidikan IPA Indonesia, $\quad 7(1), \quad$ 41-47. https://doi.org/10.15294/jpii.v6i2.723 9

Adawiyah, R. Al, Lesmono, A. D., \& Prastowo, S. H. B. (2018). Pengembangan Bahan Ajar Fisika Berupa Buku Berbasis REACT (Relating, Experiencing, Applying, Cooperating, and Transferring) pada Pembelajaran Fisika di SMA. Jurnal Pembelajaran Fisika, 7(2), 202-209.

Agustin, H. A., Bektiarso, S., \& Bachtiar, R. W. (2018). Pengembangan Modul Komik Fisika pada Pokok Bahasan Hukum Kepler di SMA Kelas XI. Jurnal Pembelajaran Fisika, 7(2), 168-174.

Anggia, P. V., \& Dra. An Fauzia Rozani Sy., M. A. (2014). Designing Photonovela As a Media in Teaching Listening to Junior High School Students. JELT, 3(1), 295-301.

Anwar, M. K. (2017). Pembelajaran Mendalam untuk Membentuk Karakter Siswa sebagai Pembelajar. Tadris: Jurnal Keguruan Dan Ilmu Tarbiyah, 2(2), 97-104. https://doi.org/10.24042/tadris.v2i2.15 59

Ardiyanti, A., Usman, M., \& Bandu, I. (2018). Pembelajaran Kosakata Bahasa Prancis dengan Media Flashcard (Studi Kasus pada Mahasiswa Sastra Prancis). Jurnal Ilmu Budaya, 6(1), 176-186.

Astuti, I. A. D., Nurullaeli, \& Nugraha, A. M. (2018). Pengembangan Pembelajaran E-Learning dengan Web Log Sebagai Alternatif Bahan Ajar Guru. Jurnal Terapan Abdimas, 3(2), 165-169.

Astuti, P. (2017). Peningkatan Motivasi dan Kemampuan Berpikir Kreatif Siswa pada Materi Pencemaran Lingkungan melalui Media Fotonovela. Jurnal Refleksi Edukatika, 8(1), 35-42.

Asyhari, A., \& Silvia, H. (2016). Pengembangan Media Pembelajaran Berupa Buletin dalam Bentuk Buku Saku untuk Pembelajran IPA Terpadu. Jurnal Ilmiah Pendidikan Fisika AlBiruni, 5(1), 1-13. https://doi.org/10.24042/jpifalbiruni.v $5 \mathrm{i} 1.100$

Barus, E. L., \& Sani, R. A. (2017). Pengaruh Model Pembelajaran Latihan Inkuiri terhadap Hasil Belajar Siswa pada Materi Pokok Usaha dan Energi di Kelas X Semester II. Jurnal Inovasi Pembelajaran Fisika, 1(1), 16-22.

Chan, A., Brown, B., Sepulveda, E., \& Teran-Clayton, L. (2015). Evaluation of fotonovela to increase human papillomavirus vaccine knowledge, attitudes, and intentions in a lowincome Hispanic community. BMC Research Notes, 8(1), 1-10. https://doi.org/10.1186/s13104-0151609-7

Chhetri, V. (2017). Challenges in Undergraduate Physics Education: A Interpretive Structural Modeling Approach. International Journal of Engineering and Management Research Page, 7(3), 372-378.

Ciffolilli, A., \& Muscio, A. (2018). Industry 4.0: national and regional comparative advantages in key enabling technologies. European Planning Studies, $\quad 0(0), \quad 1-21$. https://doi.org/10.1080/09654313.201 8.1529145

Damayanti, A. E., Komikesari, H., Syafei, I., \& Rahayu, R. (2018). Kelayakan Media Pembelajaran Fisika Berupa Buku Saku Berbasis Android Pada Materi Fluida Statis. Indonesia Journal of Science and Mathematics Education, 01(1), 63-70.

Diani, R. (2015). Pengembangan Perangkat Pembelajaran Fisika Berbasis Pendidikan Karakter dengan Model Problem Based Instruction. Jurnal Ilmiah Pendidikan Fisika Al-Biruni, 4(2), 
https://doi.org/10.24042/jpifalbiruni.v $4 \mathrm{i} 2.96$

E.P, R. H., Bektiarso, S., \& Gani, A. A. (2017). Model Pembelajaran Generatif (Generative Learning) dilengkapi Media Kartu Masalah pada Pembelajaran Fisika di SMA (Studi pada Materi Elastisitas di SMA N 1 Pakusari). Jurnal Pembelajaran Fisika, 5(4), 399-403.

Haruehansawasin, S., \& Kiattikomol, P. (2018). Scaffolding in Problem-Based Learning for Low-Achieving Learners. Journal of Educational Research, 111(3), 363-370. https://doi.org/10.1080/00220671.201 7.1287045

Herdiani, H., Maskur, \& Noordyana, M. A. (2017). Efektitivitas Media Fotonovela terhadap Mata Pelajaran Bahasa Indonesia pada Siswa Tunagrahita SLB B-C YGP Selaawi Tahun Pelajaran 2016/2017. Jurnal Teknologi Pendidikan Dan Pembelajaran, 2(1), 151-161.

Hofer, S. I., Schumacher, R., Rubin, H., \& Stern, E. (2018). Enhancing Physics Learning With Cognitively Activating Instruction: A Quasi-Experimental Classroom Intervention Study. Journal of Educational Psychology, 1-17. https://doi.org/10.1037/edu0000266

Irmawati, Djalaluddin, M., \& Wahyuni, A. (2017). Pengaruh Model Pembelajaran Kooperatif Physics Mysterious Berbasis Fun Learning terhadap Minat dan Hasil Belajar. Jurnal Pendidikan Fisika, 5(1), 6-9.

Irwandani, Latifah, S., Asyhari, A., Muzannur, \& Widayanti. (2017). Modul Digital Interaktif Berbasis Articulate Studio'13: Pengembangan pada Materi Gerak Melingkar Kelas X. Jurnal Ilmiah Pendidikan Fisika AlBiruni, 06(2), 221-231. https://doi.org/10.24042/jipfalbiruni.v $6 \mathrm{i} 2.1862$

Khoiron, A. M., \& Sutadji, E. (2012). Kontribusi Implementasi Pendidikan Karakter dan Lingkungan Sekolah terhadap Berpikir Kreatif serta
Dampaknya pada Kompetensi Kejuruan. Jurnal Pendidikan Dan Pembelajaran, 22(2), 103-116.

Koops van 't Jagt, R., Hoeks, J. C. J., Duizer, E., Baron, M., Molina, G. B., Unger, J. B., \& Jansen, C. J. M. (2018). Sweet Temptations: How Does Reading a Fotonovela About Diabetes Affect Dutch Adults with Different Levels of Literacy? Health Communication, 33(3), 284-290. https://doi.org/10.1080/10410236.201 6.1258617

Maiyena, S. (2013). Pengembangan Media Poster Berbasis Pendidikan Karakter untuk Materi Global Warming. Jurnal Materi Dan Pembelajaran Fisika (JMPF), 3(1), 18-26.

Mujizatullah. (2018). Pengintegrasian Pendidikan Karakter Keagamaan pada Pembelajaran Hakikat Ilmu Fisika dan Keselamatan Kerja di Laboratorium Madrasah Aliyah Puteri Aisyiah di Palu. Jurnal Pendidikan Fisika Universitas Muhammadiyah Makassar, 6(2), 115-128.

Muslina, Abdul, H., \& Ibnu, K. (2017). Kelayakan Media Animasi Hukum Newton II tentang Gerak pada Bidang Miring dan Katrol di SMA Kabupaten Aceh Besar. Jurnal IPA Dan Pembelajaran IPA, 1(1), 64-72.

Nugraha, A. (2017). Pengembangan Media Komik Motivasi Berprestasi sebagai Layanan Bimbingan Pribadi bagi Siswa SMP Muhammadiyah 1 Godean. Jurnal Riset Mahasiswa Bimbingan Dan Konseling, 3(6), 465473.

Nurhuda, T. A., Waluyo, H. J., \& Suyitno. (2017). Novel Simple Miracles Karya Ayu Utami Serta Relevansinya pada Pembelajaran Sastra di SMA. Jurnal Ilmiah Didaktika, 18(1), 103-117.

Oktaviani, R., Yulkifli, \& Murtiani. (2017). Pengaruh Penerapan Bahan Ajar Bermuatan Nilai-Nilai Karakter dalam Model Pembelajaran SAVI terhadap Kompetensi Fisika Peserta Didik pada Materi Momentum, Impuls dan Getaran Harmonis Kelas X MIPA 
SMAN 2 Bukittinggi. Jurnal Berkala Ilmiah Pendidikan Fisika, 10, 113120.

Rahayu, A., Sutikno, S., \& Masturi, M. (2015). Pengembangan Media Pembelajaran Hukum Newton menggunakan Fotonovela Berbasis Kearifan Lokal. Prosiding Seminar Nasional Fisika, IV, 33-37.

Ramadhanti, M., Edwita, \& Sumantri, M. S. (2018). Media Pembelajaran BCCT (Beyond Center and Circle Time) Berbasis Multiple Intelligences. Jurnal Ilmiah PGSD, 2(1), 55-66.

Rosdianto, H., Murdani, E., \& Hendra. (2017). Implementasi Model Pembelajaran POE (Predict Observe Explain) untuk Meningkatkan Pemahaman Konsep Siswa pada Materi Hukum Newton. Jurnal Pendidikan Fisika, 6(1), 55-59.

Rubiyanto, E., \& Susanto, A. (2018). Pengembangan Media Pembelajaran Sistem Kemudi Tipe Rack and Pinion untuk Meningkatkan Hasil Belajar Siswa pada Mata Pembelajaran Chassis Kelas XI SMK Patriot Pituruh. Jurnal Pendidikan Teknik Otomotif_Universitas Muhammadiyah Purworejo, 12(01), 56-61.

Saregar, A. (2016). Pembelajaran Pengantar Fisika Kuantum dengan Memanfaatkan Media PhET Simulation dan LKM Melalui Pendekatan Saintifik: Dampak pada Minat dan Penguasaan Konsep Mahasiswa. Jurnal Ilmiah Pendidikan Fisika Al-Biruni, 5(1), 53-60. https://doi.org/10.24042/jpifalbiruni.v 5i1.105

Saregar, A., Diani, R., \& Kholid, R. (2017). Efektivitas Penerapan Model Pembelajaran ATI (Aptitude Treatment Interaction) Dan Model Pembelajaran TAI (Team Assisted Individualy) : Dampak Terhadap Hasil Belajar Fisika Siswa. Jurnal Pendidikan Fisika Dan Keilmuan, 3(1), 28-35.

Saregar, A., Latifah, S., \& Sari, M. (2016). Efektivitas Model Pembelajaran
CUPs: Dampak terhadap Kemampuan Berpikir Tingkat Tinggi Peserta Didik Madrasah Aliyah Mathla'ul Anwar Gisting Lampung. Jurnal Ilmiah Pendidikan Fisika Al-Biruni, 05(2), 233-243.

https://doi.org/10.24042/jpifalbiruni.v $5 \mathrm{i} 2.123$

Sari, N., Suryanti, K., Manurung, S. M., \& Sintia. (2017). Analisis Penggunaan Media Pembelajaran untuk Meningkatkan Motivasi Peserta Didik terhadap Pembelajaran Fisika Kelas XI MIPA 1 SMA Titian Teras Muaro Jambi. Pendidikan Fisika Dan Keilmuan (JPFK), 3(2), 110-112.

Sari, R. T., \& Jusar, I. R. (2017). Analisis Kebutuhan Modul Pembelajaran IPA Berorientasi Pendidikan Karakter melalui Pendekatan Quantum Learning di Sekolah Dasar. Jurnal Pendidikan Biologi Universitas Muhammadiyah Metro, 8(1), 26-32.

Setiawan, D., Arifin, I., \& Ardianto, R. (2018). Implementasi Pengembangan Sistem Media Pembelajaran Pengenalan Komputer: Program Studi Sistem Informasi Universitas PGRI Madiun. Intensif, 2(2), 127-135. https://doi.org/10.29407/intensif.v2i2. 12099

Sole, F. B., \& Anggraeni, D. M. (2016). Pengembangan Instrumen Penilaian Sikap Ilmiah Sains Siswa Sekolah Dasar (SD) Berbasis Pendidikan Karakter. Jurnal Penelitian Pendidikan IPA, 3(2), 99-105.

Sugiana, I. N., Harjono, A., \& Sahidu, H. (2016). Pengaruh Model Pembelajaran Generatif Berbantuan Media Laboratorium Virtual Terhadap Penguasaan Konsep Fisika Siswa pada Materi Momentum dan Impuls. Jurnal Pendidikan Fisika Dan Keilmuan, 2(2), 61-65.

Suranti, N. M. Y., Gunawan, G., \& Sahidu, H. (2016). Pengaruh Model Project Based Learning Berbantuan Media Virtual Terhadap Penguasaan Konsep Peserta didik pada Materi Alat-alat Optik. Jurnal Pendidikan Fisika Dan 
Teknologi, 2(2), 73-79.

Suryani, N. A., Sakti, I., \& Purwanto, A. (2018). Perbedaan Hasil Belajar Antara Model Pembelajaran Clis (Children'S Learning in Science) dengan menggunakan Media Kit IPA di SMP Negeri 21 Kota Bengkulu. PENDIPA Journal of Science Education, 2(1), 113-116.

Suyanto, S. (2018). Magnetic Swings and Magic Circle: Belajar Cerdas Induksi Magnetik dengan Barang Bekas melalui Pendekatan Pembelajaran Fisika Berbasis Inkuiri (Level of Inkuiri Based Learning). Jurnal Penelitian Pembelajaran Fisika, 9(1), 53.

https://doi.org/10.26877/jp2f.v9i1.234 5

Unger, J. B., Cabassa, L. J., Molina, G. B., Contreras, S., \& Baron, M. (2013). Evaluation of a Fotonovela to Increase Depression Knowledge and Reduce Stigma Among Hispanic Adults. $J$ Immigr Minor Health, 15(2), 398-406. https://doi.org/10.1021/nn300902w.Re lease

Venisari, R., Gunawan, \& Sutrio. (2015). Penerapan Metode Mind Mapping pada Model Direct Instruction untuk Meningkatkan Kemampuan Pemecahan Masalah Fisika Siswa SMPN 16 Mataram. Jurnal Pendidikan Fisika Dan Teknologi, I(3), 193-198.

Weng, W. Y., Lin, Y. R., \& She, H. C. (2017). Scaffolding for argumentation in hypothetical and theoretical biology concepts. International Journal of Science Education, 39(7), 877-897. https://doi.org/10.1080/09500693.201 7.1310409

Wicaksono, H., Roekhan, \& Hasanah, M. (2018). Pengembangan Media Permainan Imajinasi dalam Pembelajaran Menulis Puisi bagi Siswa Kelas X. Jurnal Pendidikan, 3(2), 223-228.

Widada, \& Rosyidi, A. (2017). Perancangan Media Pembelajaran Fisika SMP Berbasis Multimedia Interaktif. Jurnal IT CIDA, 3(2), 53-68.
Widyaningrum, R., \& Prihastari, E. B. (2018). Implementasi model pembelajaran talking chips disertai media fotonovela untuk meningkatkan sikap peduli lingkungan dan kemampuan menyampaikan pendapat mahasiswa. Jurnal Pendidikan Dasar Dan Pembelajaran, 8(1), 22. https://doi.org/10.25273/pe.v8i1.2033

Widyaningsih, S. W., \& Yusuf, I. (2015). Penerapan Pembelajaran Listrik Dinamis Model Kooperatif Tipe STAD menggunakan Pendekatan CTL dengan Integrasi Nilai-Nilai Karakter terhadap Aktivitas dan Hasil Belajar Peserta Didik. Jurnal Universitas Jember, 4(2), 223-234.

Yusro, A. C., \& Sasono, M. (2016). Penggunaan Modul Ilustratif Berbasis Inkuiri Terbimbing Pokok Bahasan Kinematika Gerak Lurus untuk Meningkatkan Hasil Belajar dan Kemandirian Siswa Kelas VII SMPN 14 Madiun. Jurnal Pendidikan Fisika Dan Keilmuan (JPFK), 2(1), 29. https://doi.org/10.25273/jpfk.v2i1.22 